\title{
Prevalence of equine infectious anemia in stud farms in Minas Gerais, Brazil
}

\section{Prevalência da anemia infecciosa equina em haras de Minas Gerais, Brasil}

\author{
Valéria Maria de Andrade Almeida ${ }^{1}$; Cairo Henrique Sousa de Oliveira ${ }^{2}$; \\ Karina Silva Fiorillo $;$; Marilda Ferreira Martins ${ }^{4}$; Rômulo Cerqueira Leites; \\ Jenner Karlisson Pimenta dos Reis ${ }^{5 *}$; Vitor Salvador Picão Gonçalves ${ }^{6}$
}

\begin{abstract}
Horse breeding is expanding in Brazil. Nevertheless, equine infectious anemia (EIA) a transmissible, incurable disease is an obstacle to the development of the horse industry. Therefore, to determine the incidence of EIA at stud farms in the state of Minas Gerais, Brazil, a serological survey was conducted to estimate the prevalence and identify potential risk factors for equine infectious anemia virus (EIAV) transmission. This was the second stage of an ongoing study on the epidemiology of the disease, which was first observed in draft horses. A sample of 7,742 equids from 717 stud farms in seven regions within the State was tested between May 2004 and January 2006. Laboratory tests including enzyme-linked immunosorbent assays and agar gel immunodiffusion were conducted for screening and confirmation, respectively. The prevalence of EIA was estimated to be $0.44 \%(95 \%$ confidence interval $[\mathrm{CI}]=0.00$ $0.871)$ at the farm level and $0.07 \%(95 \% \mathrm{CI}=0.00-0.251)$ at the animal level. The low prevalence of EIA in stud farms might be explained by the higher zootechnical value of stable-bred animals, which leads to periodical serological control and compliance with the slaughter of test-positive animals in order to keep the farm EIA-free. Moreover, stable-bred horses usually travel more and are subjected to more official controls than are draft horses. The highest prevalence of EIA was observed in regions 1 (North/ Northwest of Minas Gerais) and 2 (Vale do Mucuri/Jequitinhonha), with rates of $0.34 \%$ and $0.72 \%$, respectively. These results show that the prevalence of EIA at stud farms in Minas Gerais is generally low, with the prevalence being higher in the northern part of the State (regions 1 and 2). A previous serological survey on EIA among draft horses showed a very similar distribution of EIA infection in Minas Gerais. These results suggest a very similar pattern of EIA distribution across the State and irrespective of zootechnical value, but the northern/northwestern regions have a higher prevalence than do the southern regions.
\end{abstract}

Key words: EIA. Equids. Epidemiology. AGID. ELISA.

\section{Resumo}

A criação de cavalos está em expansão no Brasil. No entanto, a anemia infecciosa equina (EIA), uma doença transmissível, incurável é um obstáculo ao desenvolvimento da indústria equidea. Dessa forma,

\footnotetext{
${ }^{1}$ Mestre em Ciência Animal, Universidade Federal de Minas Gerais, UFMG, Belo Horizonte, MG, Brasil. E-mail: valerinha. almeida@gmail.com

2 Prof. Adjunto, Universidade Federal de Goiás, UFG, Goiânia, GO, Brasil. E-mail: cairo_henrique@yahoo.com.br

3 Mestre em Saúde Animal, Universidade de Brasília, UNB, DF, Brasil. E-mail: karinasfiorillo@gmail.com

${ }^{4}$ M.e em Ciência Animal, UFMG, Belo Horizonte, MG, Brasil. E-mail: marildafmartins@gmail.com

${ }^{5}$ Profs. Titular, Departamento de Medicina Veterinária Preventiva da Escola de Veterinária, UFMG, Belo Horizonte, MG, Brasil. E-mail: romulocleite@ufmg.br; jenner@ufmg.br

${ }^{6}$ Prof. Associado, Universidade de Brasília, UNB, Brasília, DF, Brasil. E-mail: vitorspg@unb.br

* Author for correspondence
} 
para determinar a incidência de AIE em haras de Minas Gerais, foi realizado um levantamento sorológico para estimar a prevalência e identificar potenciais fatores de risco para a transmissão do vírus da anemia infecciosa equina (EIAV). Esta foi a segunda etapa de um estudo em curso sobre a epidemiologia da doença, que foi realizado pela primeira vez em animais de serviço. Uma amostra de 7.742 equídeos de 717 fazendas em sete regiões do Estado foi testada entre maio de 2004 e janeiro de 2006. Testes de laboratório incluindo ensaios imunoenzimáticos e a imunodifusão em gel de ágar foram conduzidos para triagem e confirmação, respectivamente. A prevalência de AIE foi estimada em 0,44\% (intervalo de confiança de $95 \%[\mathrm{IC}]=0,00-0,871$ ) ao nível de propriedade e $0,07 \%$ (IC 95\% = 0,00-0,251) ao nível animal. A baixa prevalência de AIE em haras pode ser explicada pelo maior valor zootécnico de animais de raça estabulados, o que leva ao controle sorológico periódico e ao cumprimento do abate de animais positivos ao teste, a fim de manter a fazenda livre da AIE. Além disso, os cavalos de haras geralmente viajam mais e são submetidos aos controles oficiais com maior frequência do que os animais de serviço. A maior prevalência de AIE foi observada nas regiões 1 (Norte / Noroeste de Minas Gerais) e 2 (Vale do Mucuri / Jequitinhonha), com taxas de $0,34 \%$ e $0,72 \%$, respectivamente. Esses resultados mostram que a prevalência de AIE em haras em Minas Gerais é geralmente baixa, sendo a prevalência maior na região norte do Estado (regiões 1 e 2). Um levantamento sorológico prévio sobre AIE em animais de serviço mostrou uma distribuição muito semelhante da doença em Minas Gerais. Estes resultados sugerem um padrão muito semelhante de distribuição da AIE em todo o Estado, independentemente do valor zootécnico, mas as regiões norte / noroeste têm uma prevalência maior do que as regiões do sul.

Palavras-chave: EIA. Equídeos. Epidemiologia. IDGA. ELISA.

\section{Introduction}

The equid species is of great importance to the Brazilian economy as it contributes more than 7 billion reals per year and employs about 3 million people directly or indirectly. Recent data showed that the total population of equids in Brazil is approximately 8 million animals, of which 5,450,601 $(70 \%)$ are horses. The southeastern region has the largest number of horses $(1,320,259)$, of which approximately $58 \%(763,780)$ are in the state of Minas Gerais, which ranks first in the country in the number of horses (IBGE, 2014).

Equine infectious anemia (EIA) is a cosmopolitan viral disease of equines (CARVALHO JUNIOR, 1998), which is caused by a RNA virus of the genus Lentivirus (ISSEL et al., 2014). The infected horse is considered a permanent source of infection, because once infected horses maintain the virus for life even without EIA clinical manifestations (McCLURE et al., 1982). The World Organization for Animal Health (OIE) and the Brazilian legislation on animal health consider this a disease that requires compulsory notification, and any positive case must be reported to animal health authorities (BRASIL, 2004; OIE, 2012). Improving health management actions and minimizing misdiagnosis are also necessary, because according to current regulations, seropositive animals must be euthanized; this imposes an economic burden on the stud farm of horses (JACOBO et al., 2006).

The agar gel immunodiffusion test (AGID) (COGGINS et al., 1972) and enzyme-linked immunosorbent assay (ELISA) (ISSEL et al., 2013) are accurate for detecting EIA, even though their accuracy is limited in animals that are in the early stages of infection and in foals of infected mares(OIE, 2012). AGID is a standardized test, recommended by the OIE for the diagnosis of EIA, and should be performed by a veterinarian and in laboratories accredited by the Ministry of Agriculture, Livestock and Food Supply (MAPA). The result of this test should be negative for animals being transported and allowed to participate in agricultural events (BRASIL, 2004). Studies at the Federal University of Minas Gerais have developed an indirect ELISA using a recombinant gp90 glycoprotein as the antigen. The results of this rgp90 ELISA showed high correlation with the results obtained using AGID. Moreover, this test has the advantage of detecting antibodies against the equine infectious 
anemia virus (EIAV) in an early stage of infection, and because it is highly sensitive, it is useful as a screening tool for use in seroepidemiological surveys of EIA (REIS et al., 2012). The MAPA has recently approved a standard protocol allowing the use of ELISA for the diagnosis of EIA. However, all samples showing positive results should be confirmed by AGID testing (BRASIL, 2014).

In this scenario, with an aim of eventually eradicating EIA, more comprehensive prevalence studies are required on animals with this disease, as well as its pathogenesis and spread in the equine population, so that more appropriate health policies can be adopted. This study was a result of another investigation performed in draft horses (ALMEIDA et al., 2006), which defined Minas Gerais as an endemic area for EIA, with a prevalence of $5.29 \%$ [95\% CI $=4.32-6.26]$ in herds and $3.08 \%$ [95\% CI $=2.21-3.95]$ in equines. This study aimed to characterize the occurrence of EIA in stud farms in the state of Minas Gerais through a seroepidemiological survey, in order to estimate the prevalence of EIA and to determine its correlation with possible risk factors. The results obtained will assist in directing disease control policies in Minas Gerais, especially when combined with the results of prevalence surveys in draft horses.

\section{Materials and Methods}

\section{Study location}

The study was carried out in the State of Minas Gerais, which is the fourth largest state in Brazil, occupying an area of $586,528 \mathrm{~km}^{2}$. Considering the large area of Minas Gerais and its operational capability for the study, the state was divided into seven regions, covering the twelve mesoregions determined by the Brazilian Institute of Geography and Statistics (IBGE, 2009), as shown in Figure 1.

To ensure that the State was not divided into numerous regions, it was established that each region should represent at least $10 \%$ of the equine population of the state. The density and geographic location of the animals (Table 1) was taken into account while grouping the mesoregions (Figure 1).

Table 1. Density of equids per square kilometer in the sampling regions of Minas Gerais, Brazil, in 2009.

\begin{tabular}{lccc}
\hline Region & $\begin{array}{c}\text { Number of } \\
\text { equids }\end{array}$ & Area $\left(\mathbf{k m}^{\mathbf{2}}\right)$ & Density \\
\hline 1 Northern/Northwestern Minas Gerais & 233,081 & 190,716 & 1.22 \\
2 Vale do Mucuri/Jequitinhonha & 146,266 & 70,327 & 2.08 \\
3 Vale do Rio Doce & 108,533 & 41,809 & 2.60 \\
4 Central Mineira/Western Minas Gerais/Metropolitan area & 168,604 & 95,304 & 1.77 \\
of Belo Horizonte & 123,242 & 49,525 & 2.49 \\
5 Southern/Southwestern Minas Gerais & 105,832 & 90,559 & 1.17 \\
6 Triângulo Mineiro/Alto Paranaíba & 174,259 & 48,312 & 3.61 \\
7 Campo das Vertentes/Zona da Mata & $\mathbf{1 , 0 5 9 , 8 1 7}$ & $\mathbf{5 8 6 , 5 5 2}$ & $\mathbf{1 . 8 1}$ \\
\hline TOTAL & &
\end{tabular}

Source: IBGE (2009).

\section{Sampling and prevalence}

The prevalence of stud farms with EIA and number of seropositive equines were estimated in each region. The property (stud farm) was considered a primary unit and the equid a secondary unit of the sampling process. To estimate the prevalence of stud farms a simple random sampling was performed in each region. In each randomly selected stud farm, a new simple sampling of horses was performed to classify the stud farm as positive or negative. The prevalence of animals was estimated considering that the sampling process described was equivalent to a two-stage cluster sampling. 
This first stage used quantitative data of stud farms in Minas Gerais that were provided by the breeders' associations of the main horse breeds in the State. A list of properties sorted by the municipality was drafted and a simple random sampling was then performed, taking into account the operational capability for the study.

Figure 1. Division of the State of Minas Gerais into seven sampling regions (IBGE, 2009).

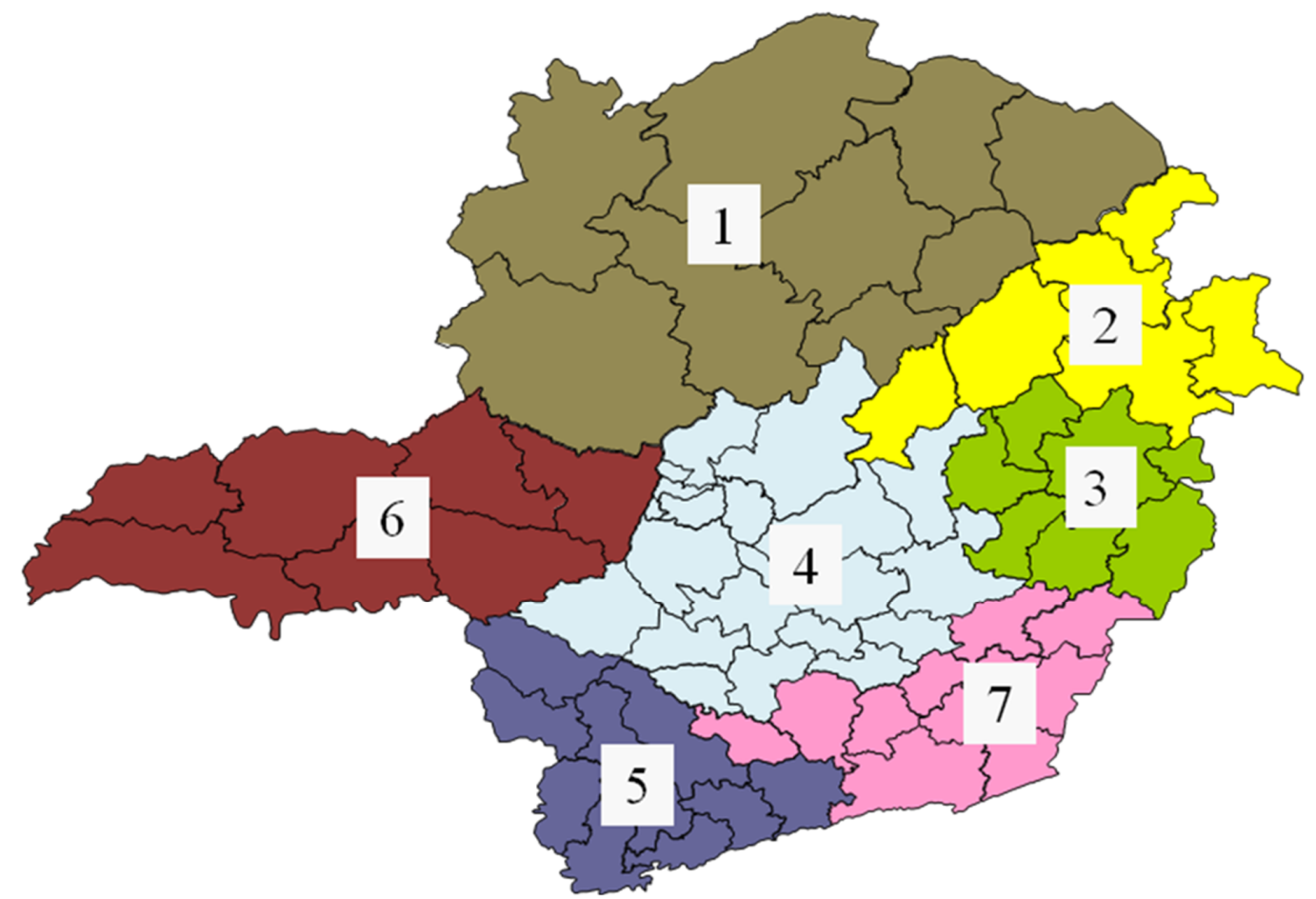

- Region 1: Mesoregions Northern and Northwestern Minas Gerais

- Region 2: Mesoregions Vale do Mucuri and Jequitinhonha

- Region 3: Mesoregion Vale do Rio Doce

- Region 4: Mesoregions Central Mineira, Western Minas Gerais, and Metropolitan Area of Belo Horizonte

- Region 5: Mesoregions Southern and Southwestern Minas Gerais

- Region 6: Mesoregions Triângulo Mineiro and Alto Paranaíba

- Region 7: Mesoregions Campo das Vertentes and Zona da Mata

The total number of stud farms to be sampled was determined by the level of accuracy and desired degree of confidence, as well as expected result of prevalence. The formula is shown below (THRUSFIELD, 1995):

$$
\mathrm{n}=\frac{\mathrm{Z}_{\alpha / 2}^{2} * \mathrm{P}(1-\mathrm{P})}{\mathrm{d}^{2}}
$$

The parameters used were the $95 \%$ confidence interval $(\mathrm{CI})\left(\mathrm{Z}_{\alpha / 2}=1.96\right)$, estimated prevalence of $5 \%(\mathrm{P}=0.05)$, and accuracy of $3 \%(\mathrm{~d}=0.03)$. Using the Epi Tools ${ }^{\circledR}$ software (SERGEANT, 2009), the number of finite populations was corrected considering the current quantitative data in each region; thus, the minimum number of samples to be collected in each region was determined.

Conservative prevalence values, i.e., values higher than actually expected, were used since there were no precise estimates for the types of stud farms included in the study. Seven hundred and seventeen stud farms (Table 2) distributed in the regions were sampled; this number was slightly less than $30 \%$ of the number of current stud farms in Minas Gerais, i.e., 2,493 registered stud farms. 
Table 2. Total number of current stud farms and number of stud farms assessed in the study by region in Minas Gerais, Brazil.

\begin{tabular}{llcc}
\hline Region & $\begin{array}{c}\text { Total number } \\
\text { of stud farms }\end{array}$ & $\begin{array}{c}\text { Sampled } \\
\text { stud farms }\end{array}$ \\
\hline$\#$ & Region & 200 & 65 \\
\hline 1 & Northern/Northwestern Minas Gerais & 170 & 66 \\
2 & Vale do Mucuri/Jequitinhonha & 130 & 66 \\
3 & Vale do Rio Doce & 881 & 172 \\
4 & Central Mineira/Western Minas Gerais/Metropolitan area of Belo Horizonte & 439 & 139 \\
5 & Southern/Southwestern Minas Gerais & 178 & 56 \\
6 & Triângulo Mineiro/Alto Paranaíba & 495 & 153 \\
7 & Campo das Vertentes/Zona da Mata & $\mathbf{2 , 4 9 3}$ & $\mathbf{7 1 7}$ \\
\hline TOTAL & & \\
\hline
\end{tabular}

After selecting the stud farms for sampling in each region, the number of equids older than 6 months to be tested for EIA was defined. According to Burns (1974), 6 months is the minimum age at which tests should be performed to avoid the interference of colostral antibodies on the serological test results.

The number of animals to be tested per stud farm was calculated on the basis of the value of aggregated sensitivity and specificity (JORDAN, 1996) determined using the Epi Tools ${ }^{\circledR}$ software (SERGEANT, 2009). Thus, a stud farm was considered positive for EIA when at least one animal reacted to the confirmatory test (DONALD; GARDNER, 1994). The number of sampled secondary units was calculated in order to obtain a value of aggregated sensitivity and specificity equal to or higher than $90 \%$.

It was determined that 10 animals would be sampled when stud farms with at least 50 equids, and all animals would be sampled when the number of equids was below 10. Fifteen animals would be sampled in stud farms that had more than 50 equids. As shown in Table 3, 7,742 equids were sampled in the seven regions, representing about $6 \%$ of the total equine population in the State. The selection of animals within the stud farms and as part of this study was based on random sampling, and the horse breeds were selected proportionally to the number of animals in each region.

Table 3. Total number of current equines and number of equids sampled in the stud farms of Minas Gerais, Brazil.

\begin{tabular}{llcc}
\hline Region & $\begin{array}{c}\text { Total number } \\
\text { of equids at } \\
\text { stud farms }\end{array}$ & $\begin{array}{c}\text { № of } \\
\text { equids } \\
\text { Sampled }\end{array}$ \\
\hline$\# \quad$ Region & 10,812 & 688 \\
2 & Northern/Northwestern Minas Gerais & 10,791 & 787 \\
3 & Vale do Mucuri/Jequitinhonha & 5,732 & 671 \\
4 & Vale do Rio Doce & 43,663 & 1,847 \\
5 & Sentral Mineira/Western Minas Gerais/Metropolitan area of Belo Horizonte & 20,951 & 1,535 \\
6 & Triângulo Mineiro/Alto Paranaíba & 10,845 & 615 \\
7 & Campo das Vertentes/Zona da Mata & 24,135 & 1,599 \\
\hline TOTAL & $\mathbf{1 2 6 , 9 2 9}$ & $\mathbf{7 , 7 4 2}$ \\
\hline
\end{tabular}




\section{Risk factors and diagnosis}

In addition to collecting blood samples for diagnostic tests, a form was filled to obtain data about the equids sampled at each stud farm, which allowed to study possible risk factors associated with EIA. The serodiagnosis protocol included a screening test using rgp90 ELISA (REIS et al., 2012), followed by a retest of positive or inconclusive samples using AGID (COGGINS et al., 1972).

\section{Statistical analysis}

The sensitivity of a stud farm (SenR) is the probability of an infected stud farm to be correctly classified as positive by the combined diagnostic testing, whereas the specificity of a stud farm (EspR) is the likelihood of a free stud farm to be correctly classified as negative. To assess the prevalence of EIA, a stud farm was considered positive when there was at least one positive animal, i.e., $\operatorname{SenR}=1-(1-\mathrm{AP}) \mathrm{N}$ and $\mathrm{EspR}=\mathrm{Esp} \times \mathrm{N}$; where $\mathrm{AP}=$ apparent prevalence and $\mathrm{N}=$ number of animals tested (NOORDHUIZEN et al., 1997). The apparent prevalence was obtained by weighting the frequency of seropositivity with the weight that each animal had on the stud farm and the weight that each stud farm had in the sample region.

The module Complex Samples Frequencies of the Epi Info 3.5.1 software (CDC, 2008) was used to estimate the prevalence of EIA outbreaks in stud farms in the State of Minas Gerais, applying the following parameters. The status of the stud farm (positive or negative for EIA), the region in which each stud farm was located, and the weight of each stud farm in the region, which was calculated as the ratio of the total number of stud farms existing and the number of sampled stud farms in each region (DEAN et al., 1994). The following calculation was used:

$$
\mathrm{P}_{1}=\frac{\text { Total number of stud farms per region }}{\text { Number of stud farms sampled per region }}
$$

The CIs were calculated using the EpiTable tool, which is part of Epi Info 6.04, by applying the probabilities given by the exact binomial distribution, since the approximation to normal distribution should not be applied to low prevalence cases. The calculation of the prevalence of animals with EIA was weighted, as recommended by Dohoo et al. (2003). The parameters used to estimate prevalence were as follows: animal status (positive or negative), the region in which the stud farm and corresponding sample was located, and the statistical weight of each sampled animal. This weight was calculated on the basis of the following formula described by Dean et al. (1994):

Weight $=$ Fraction $1 \times$ Fraction 2

Fraction $1=\frac{\text { Total number of animals in the stud farm }}{\text { Total number of animals sampled in the stud farm }}$
Fraction $2=\frac{\text { Total number of equines in the region }}{\text { Total number of equines sampled in the region }}$

Fraction 1 calculates the weight of each selected animal in a stud farm. Fraction 2 calculates the weight of each sampled animal in the region.

Exploratory analyses were carried out to identify possible risk factors for EIA considering two aspects: risk that a stud farm is considered infected and risk that an animal is positive for EIA. The correlations between variables (sex, age, and region in which the stud farm is located) and the presence of EIA were evaluated using the chi-square test. The correlations were considered significant when the p-value was less than or equal to 0.05 . The calculations were performed using SPSS software version 16.0 (IBM SPSS Software). The odds ratio (OR) was also calculated to estimate the strength of the correlation between the parameters and the result of the diagnostic test. As more than $97 \%$ of all tested equines were horses $(7,546)$ and as all the positive 
horses were included in this group, this feature was not assessed as a risk factor. As for the variable "breed," because the sample consisted of different breeds and few animals were positive, no statistical analysis of this variable was taken into account.

To assess the variable "size of the stud farm" as a risk factor for EIA, the Epi Tools ${ }^{\circledR}$ software was used (SERGEANT, 2009). The statistical method used was the Mantel-Haenszel chi-square test, which aimed to control the effect of the factor "stud farm location." No multivariate data analysis was carried out since the prevalence was very low, which greatly reduced the number of positive cases associated with any risk variable.

\section{Results and Discussion}

Table 4 shows the results of the prevalence of focus of EIA in stud farms in each region and the overall prevalence in the state. The results of this study showed that EIA was only identified in region 1 (mesoregions North/Northwest of Minas Gerais), with a prevalence of $1.54 \%$; region 2 (mesoregions Vale do Mucuri/Jequitinhonha), with a prevalence of 3.03\%; and region 7 (mesoregions Campo das Vertentes/Zona da Mata), with a prevalence of $0.65 \%$. The overall prevalence of EIA in stud farms in the State of Minas Gerais was $0.44 \%$ with a $95 \%$ CI ranging from $0.15 \%$ to $1.42 \%$.

Table 4. Prevalence of focus of EIA in stud farms by region in Minas Gerais, Brazil.

\begin{tabular}{|c|c|c|c|c|c|}
\hline \multicolumn{2}{|c|}{ Region } & \multirow{2}{*}{$\begin{array}{c}\text { Sampled } \\
\text { stud } \\
\text { farms }\end{array}$} & \multirow{2}{*}{$\begin{array}{c}\text { AGID- } \\
\text { positive } \\
\text { stud farms }\end{array}$} & \multirow{2}{*}{$\begin{array}{l}\text { Prevalence } \\
\text { (\%) }\end{array}$} & \multirow{2}{*}{$\begin{array}{l}95 \% \text { Confidence } \\
\text { interval }(\%)^{(1)}\end{array}$} \\
\hline \# & Region & & & & \\
\hline 1 & Northern/Northwestern Minas Gerais & 65 & 1 & 1.54 & $0.04-8.28$ \\
\hline 2 & Vale do Mucuri/Jequitinhonha & 66 & 2 & 3.03 & $0.37-10.52$ \\
\hline 3 & Vale do Rio Doce & 66 & 0 & 0 & $0.00-5.43$ \\
\hline 4 & $\begin{array}{l}\text { Central Mineira/Western Minas Gerais/ } \\
\text { Metropolitan area of Belo Horizonte }\end{array}$ & 172 & 0 & 0 & $0.00-2.12$ \\
\hline 5 & Southern/Southwestern Minas Gerais & 139 & 0 & 0 & $0.00-2.62$ \\
\hline 6 & Triângulo Mineiro/Alto Paranaíba & 56 & 0 & 0 & $0.00-6.37$ \\
\hline 7 & Campo das Vertentes/Zona da Mata & 153 & 1 & 0.65 & $0.00-3.59$ \\
\hline \multicolumn{2}{|c|}{ TOTAL } & 717 & 4 & 0.44 & $0.15-1.42$ \\
\hline
\end{tabular}

(1) Confidence interval calculated using EpiTable

The stud farms usually maintain horses of high zootechnical value; therefore, the economic burden of having to euthanize an infected animal to prevent the spread of disease is very high. Nevertheless, a negative EIA test result is mandatory for animals in transit; animals up for sale; and animals participating in agricultural events, competitions, or used for breeding purposes. The negative test result is also required for the issuance of animal transport waybills (BRASIL, 2004). The horses at these types of stud farms are frequently transported to different locations and are, therefore, more controlled by the
Official Veterinary Service. This may explain the lower prevalence of $0.44 \%(95 \% \mathrm{CI}=0.00-0.871)$ at such stud farms than at farms for draft horses (prevalence, 5.29\%; 95\% CI=4.32-6.26) found previously by Almeida et al. (2006).

The true prevalence (TP) of stud farms positive for EIA was calculated on the basis of the AP in each region $(\operatorname{SenR}=96.63 \%$, and $\mathrm{EspR}=100 \%)$ by using the following formula defined by Martin et al. (1992): $\quad \mathrm{TP}=(\mathrm{AP}+\mathrm{EspR}-1) /(\mathrm{SenR}+\mathrm{EspR}-1)$. The results demonstrated that the AP is a good approximation of the TP (Table 5). 
Table 5. Estimated true prevalence (TP) for stud farms considering the apparent prevalence (AP) in each region (sensitivity of a stud farm $[\operatorname{SenR}]=96.63 \%$ and specificity of a stud farm $[$ EspR $]=100 \%$ ).

\begin{tabular}{ccc}
\hline Sample region & AP & TP \\
\hline 1 & 1.54 & 1.59 \\
2 & 3.03 & 3.13 \\
3 & 0 & 0 \\
4 & 0 & 0 \\
5 & 0 & 0 \\
6 & 0 & 0 \\
7 & 0.65 & 0.67 \\
Minas Gerais & $\mathbf{0 . 4 4}$ & $\mathbf{0 . 4 5}$ \\
\hline
\end{tabular}

Table 6 shows that the highest prevalence of EIA was for stud farms in region 1 (North/Northwest of Minas Gerais) with $0.339 \%$ prevalence and region 2 (Vale do Mucuri/Jequitinhonha) with $0.716 \%$ prevalence. Regions 3, 4, 5, and 6 showed no test-positive farms. The overall prevalence of animals in stud farms in the state of Minas Gerais was estimated to be $0.07 \%(95 \% \mathrm{CI}=0.00-0.251)$. The AP was converted into the TP in relation to the equines infected with EIAV in each region; the result is described in Table 7. The value that was found was considerably lower than the value obtained by Almeida et al. (2006) for draft horses in Minas Gerais.

Exploratory analyses showed that the region in which a stud farm is located was a risk factor for it to have EIA outbreaks. One hundred and thirty-one (18.3\%) stud farms out of the 717 sampled farms were located in regions 1 and 2, which were classified as northern regions because of their location in the state, whereas the other regions were classified as southern regions. Among the 586 properties in the southern region, only one tested positive for EIA, whereas among the 131 properties in the northern region, three tested positive (Table 8 ).

The results showed that the location in the state is a possible risk factor for EIA, as the northern regions had a higher prevalence of EIA than did the southern regions $(p=0.003)$. The ORs indicated that stud farms located in the northern region were almost 14-fold more likely to have EIA than were stud farms located in the southern region of the state.
A previous study on draft horses also showed that the highest prevalence of EIA was in the northern regions of the state, i.e., North/Northwest Minas Gerais with a prevalence of $14.9 \%$ and Vale do Mucuri/Jequitinhonha with a prevalence of $12.5 \%$ (ALMEIDA et al., 2006).

The northern regions are predominated by stud farms with a low degree of technological advancement and less veterinary care. The weather and other environmental conditions in these regions are also believed to favor the proliferation of blood-sucking insects such as horseflies, which are important vectors in the mechanical transmission of EIAV, as reported by Carvalho Junior (1998). These factors contribute to the higher prevalence of EIA in the northern regions.

Moreover, in most cases, the disease is asymptomatic (ISSEL; COGGINS, 1979; SELLON, 1993). This characteristic of EIA prevents the owners from recognizing the disease and taking actions to prevent the further spread of the disease, especially immediate euthanasia of carriers and restriction of equine traffic until the location of the outbreak is sanitized.

The second variable assessed was the size of the stud farms. Each of the stud farms sampled had 4 to 400 equids, and about $10 \%$ of the stud farms had all their equids tested because they had less than 10 animals. It was also observed that more than $75 \%$ of the stud farms had up to 50 animals, as shown in Table 9. 
Table 6. EIA prevalence among equids in stud farms in each region of Minas Gerais, Brazil.

\begin{tabular}{llcccc}
\hline Region & Region & $\begin{array}{c}\text { Equids } \\
\text { Sampled }\end{array}$ & $\begin{array}{c}\text { AGID } \\
\text { positive } \\
\text { equids }\end{array}$ & $\begin{array}{c}\text { AP } \\
\text { (\%) }\end{array}$ & $\begin{array}{c}\mathbf{9 5 \%} \\
\text { Confidence } \\
\text { interval (\%) }\end{array}$ \\
\hline 1 & Northern/Northwestern Minas Gerais & 688 & 2 & 0.34 & $0.00-1.01$ \\
2 & Vale do Mucuri/Jequitinhonha & 787 & 5 & 0.72 & $0.00-2.20$ \\
3 & Vale do Rio Doce & 671 & 0 & 0 & 0.00 \\
4 & Central Mineira/Western Minas Gerais/ & 1,847 & 0 & 0 & 0.00 \\
5 & Metropolitan area of Belo Horizonte & 1,535 & 0 & 0 & 0.00 \\
6 & Southern/Southwestern Minas Gerais & 615 & 0 & 0 & 0.00 \\
7 & Triângulo Mineiro/Alto Paranaíba & 1,599 & 1 & 0.08 & $0.00-0.25$ \\
\hline TOTAL & Campo das Vertentes/Zona da Mata & $\mathbf{7 , 7 4 2}$ & $\mathbf{8}$ & $\mathbf{0 . 0 7}$ & $\mathbf{0 . 0 0 - 0 . 2 5}$ \\
\hline
\end{tabular}

Table 7. True prevalence (TP) for equids considering the apparent prevalence (AP) in each region (sensitivity of a stud farm $[$ SenR $]=96.63 \%$ and specificity of a stud farm $[$ EspR $]=100 \%$ ).

\begin{tabular}{ccc}
\hline Sample region & AP & TP \\
\hline 1 & 0.34 & 0.35 \\
2 & 0.72 & 0.74 \\
3 & 0 & 0 \\
4 & 0 & 0 \\
5 & 0 & 0 \\
6 & 0 & 0 \\
7 & 0.08 & 0.083 \\
Minas Gerais & $\mathbf{0 . 0 7}$ & $\mathbf{0 . 0 7 2}$ \\
\hline
\end{tabular}

Table 8. Frequency of EIA-positive stud farms according to their location in the state of Minas Gerais, Brazil.

\begin{tabular}{lcccc}
\hline & & Result & Total \\
\cline { 3 - 5 } & & Negative & Positive & 586 \\
Location & South & 585 & 1 & $81.7 \%$ \\
& & $81.6 \%$ & $0.1 \%$ & 131 \\
& North & 128 & 3 & $18.3 \%$ \\
Total & $17.9 \%$ & $0.4 \%$ & $\mathbf{7 1 7}$ \\
\hline
\end{tabular}

$\mathrm{p}=0.003 \quad \mathrm{OR}=13.42(1.41-127.99)$.

Table 9. Number of equids in the sampled stud farms of Minas Gerais, Brazil.

\begin{tabular}{lc}
\hline & Number of equines per stud farm \\
\hline Minimum & 4 \\
First quartile & 16 \\
Second quartile or median & 30 \\
Third quartile & 50 \\
Maximum & 400 \\
Mean & 43 \\
\hline
\end{tabular}


As shown in Table 10, the Mantel-Haenszel chisquare test showed no correlation between the size of the stud farm and the fact that it was positive for EIA, irrespective of whether the stud farm was located in the northern or southern region.

In this study, 2,673 males and 5,069 females were sampled. The chi-square test results showed no correlation between sex and the prevalence of EIA ( $p=0.190)$, corroborating the results of Almeida et al. (2006) and Santos et al. (2001).
Finally, animals in different age groups were assessed, and $45 \%$ of the sampled equines were less than 60 months (5 years) old. Horses live on average 25 years, reaching adulthood in 5 years and typically breeding from the age of 2.5 years. In this context, the correlation between the prevalence of EIA and the age of the animals was assessed after dividing the animals into two categories: young animals (under 5 years) and adult animals (over 5 years) (Table 11). The analysis revealed no statistically significant correlations between the age of the animal and the prevalence of EIA $(p=0.066)$.

Table 10. Frequency of EIA-positive stud farms according to the size of the stud equids, stratified by the location of the stud farms (Northern/Southern region) in Minas Gerais, Brazil.

\begin{tabular}{|c|c|c|c|c|}
\hline \multirow[b]{2}{*}{ Location } & & \multicolumn{3}{|c|}{ Result } \\
\hline & & Negative & Positive & Total \\
\hline \multirow{4}{*}{ Northern region } & More than 50 & 38 & 2 & 40 \\
\hline & & $5.30 \%$ & $0.28 \%$ & $5.58 \%$ \\
\hline & Less than or equal to 50 & 90 & 1 & 91 \\
\hline & & $12.55 \%$ & $0.14 \%$ & $12.69 \%$ \\
\hline \multirow{4}{*}{ Southern region } & More than 50 & 118 & 1 & 119 \\
\hline & & $16.46 \%$ & $0.14 \%$ & $16.60 \%$ \\
\hline & Less than or equal to 50 & 467 & 0 & 467 \\
\hline & & $65.13 \%$ & $0.00 \%$ & $65.13 \%$ \\
\hline Total & & 713 & 4 & 717 \\
\hline
\end{tabular}

North: Mantel-Haenszel $(\mathrm{MH})$ chi-square test $=0.55 ; \mathrm{p}=0.45 ; \mathrm{MH}$ OR=4.74 (0.42-53.82)

South: $\mathrm{MH}$ chi-square test=1.08; $\mathrm{p}=0.30 ; \mathrm{MH} \mathrm{OR}=11.84$ (0.48-292.38).

Table 11. Frequency of EIA-positive animals in stud farms, according to the age group.

\begin{tabular}{llccc}
\hline & & \multicolumn{3}{c}{ Result } \\
\cline { 3 - 4 } & & Negative & Positive & Total \\
\hline \multirow{3}{*}{ Age } & Adult (> $\mathbf{6 0}$ months) & 4,266 & 7 & 4,273 \\
& & $55.10 \%$ & $0.09 \%$ & $55.19 \%$ \\
& Young (up to 59 months) & 3,468 & 1 & 3,469 \\
\hline Total & & $44.80 \%$ & $0.01 \%$ & $44.81 \%$ \\
\hline
\end{tabular}




\section{Conclusions}

EIA is a disease found in stud farms in the State of Minas Gerais. However, the prevalence of EIA is very low in these stud farms than in farms for draft horses. Similar to the results of a previous study carried out on draft horses, the current study on stud farms also found significant regional differences between two epidemiologically distinct areas. A higher prevalence of EIA was found in the northern regions and a significantly lower prevalence was found in the southern regions. The location within the state is a possible risk factor for EIA, since a statistical analysis showed that stud farms located in the northern region were almost 14-fold more likely to have EIA than did stud farms located in the southern region of Minas Gerais.

\section{Acknowledgements}

We thank the Agricultural Institute of Minas Gerais (IMA) for collecting the material, application of the data collection form, and the partial realization of laboratory analysis; the INCT-Pecuária, CNPq, and FAPEMIG (project CVZ 193.03) for financially supporting the project; and Professor Erna Geissen Kroon for providing the rgp90 antigen used in ELISA.

\section{References}

ALMEIDA, V. M.A.; GONÇALVES, V. S. P.; MARTINS, M. F.; HADDAD, J. P. A.; DIAS, R. A.; LEITE, R. C.; REIS, J. K. P. Anemia infecciosa equina: prevalência em equídeos de serviço em Minas Gerais. Arquivo Brasileiro de Medicina Veterinária e Zootecnia, Belo Horizonte, v. 58, n. 2, p. 141-148, 2006.

BRASIL. Instrução Normativa $N^{\circ} 45$, de 15 de junho de 2004. Secretaria de Defesa Agropecuária do Ministério da Agricultura, Pecuária e Abastecimento. Normas para controle e prevenção da AIE. Diário Oficial [da] União, Brasília, DF, 2004. Seção 1, p. 7. Disponível em: $<$ http://www.agricultura.gov.br $>$. Normas para controle e prevenção da AIE. Acesso em: 12 jun. 2010.
Portaria No 378 , de 17 de dezembro de 2014. Secretaria de Defesa Agropecuária do Ministério da Agricultura, Pecuária e Abastecimento. Normas para credenciamento e monitoramento de laboratórios de diagnóstico de Anemia Infecciosa Equina. Diário Oficial [da] União, Brasília, DF, 2014. Seção 1, p. 19.12; 136.

BURNS, S. J. Equine infectious anemia: plasma clearance times of passively transferred antibody in foals. Journal of American Veterinary Medical Association, Illinois, v. 164, n. 1, p. 64-65, 1974.

CARVALHO JUNIOR, O. M. Anemia infecciosa equinaA AIDS do cavalo. Revista de Educação Continuada do $C R M V$-SP, São Paulo, v. 1, n. 1, p. 16-23, 1998.

CENTER FOR DISEASE CONTROL AND PREVENTION - CDC. Epi Info 3.5.1. Atlanta: CDC, 2008. Available at: <http://www.cdc.gov/epiinfo>. Accessed at: 7 jun. 2010.

COGGINS, L.; NORCROSS, N. L.; NUSBAUM, S. R. Diagnosis of equine infectious anemia by immunodiffusion test. American. Journal Veterinary Research, Schaumburg, v. 33, n. 1, p. 11-18, 1972.

DEAN, A. G.; DEAN, J. A.; COLOMBIER, D.; BRENDEL, K. A.; SMITH, D. C.; BURTON, A. H.; DICKER, R. C.; SULLIVAN, K.; FAGAN, R. F.; ARNER, T. G. Epi-Info. a word processing database and statistics program for epidemiology on microcomputers. Version 6. Atlanta: CDC, 1994. 601 p.

DOHOO, I.; MARTIN, W.; STRYHN, H. Veterinary epidemiologic research. Charlottetown: Atlantic Veterinary College, 2003. 706 p.

DONALD, A. W.; GARDNER, I. A. Cutt-off points for aggregate herd testing in the presence of disease clustering and correlation of test errors. Preventive Veterinary Medicine, Amsterdam, v. 19, n. 3-4, p. $167-$ 187, 1994.

INSTITUTO BRASILEIRO DE GEOGRAFIA E ESTATÍSTICA - IBGE. Pesquisa Pecuária Municipal. Brasília: Ministério do Planejamento, Desenvolvimento e Gestão, 2009. Disponível em: <http://www.sidra.ibge. gov.br/bda/tabela/protabl.asp? $\mathrm{c}=73 \& \mathrm{z}=\mathrm{t} \& \mathrm{o}=23 \& \mathrm{i}=\mathrm{P}>$. Acesso em: 20 out. 2010.

Pesquisa Pecuária Municipal. Brasília: Ministério do Planejamento, Desenvolvimento e Gestão, 2014. Disponível em: <http://www.ibge.gov.br/home/ estatistica/economia/ppm/2014/default.shtm>. Acesso em: 20 nov. 2014. 
ISSEL, C. J.; COGGINS, L. Equine infectious anemia: current knowledge. Journal of American Veterinary Medical Association, Illinois, v. 174, n. 7, p. 727-733, 1979.

ISSEL, C. J.; COOK, R. F.; MEALEY, R. H.; HOROHOV, D. W. Equine infectious anemia in 2014: live with it or erradicate it? Veterinary Clinics of North America: Equine Practice, Amsterdam, v. 30, n. 3, p. 561-577, 2014.

ISSEL, C. J.; SCICLUNA, M. T.; COOK, S. J.; COOK, R. F.; CAPRIOLI, A.; RICCI, I.; ROSONE, F.; CRAIGO, J. K.; MONTELARO, R. C.; AUTORINO, G. L. Challenges and proposed solutions for more accurate serological diagnosis of equine infectious anemia. Veterinary Record, London, v. 172, n. 8, p. 1-8, 2013.

JACOBO, R. A.; STORANI, C. A.; STAMATI, G. M.; MARTINEZ, D. E. Reações não específicas no diagnóstico da anemia infecciosa equina. A Hora Veterinária, Porto Alegre, v. 26, n. 151, p. 35-37, 2006.

JORDAN, D. Aggregate testing for evaluation of Johne's disease herd status. Australian Veterinary Journal, Queensland, v. 73, n. 1, p. 16-19, 1996.

MARTIN, S. W.; SHOUKRI, M.; THORBURN, M. A. Evaluating the health status of herds based on tests applied to individuals. Preventive Veterinary Medicine, Amsterdam, v. 14, n. 1-2, p. 33-43, 1992.

McCLURE, J. J.; LINDSAY, W. A.; TAYLOR, W.; OCHOA, R.; ISSEL, C. J.; COULTER, S. J. Ataxia in four horses with equine infectious anemia. Journal of American Veterinary Medical Association, Illinois, v. 180, n. 3, p. 279-83, 1982.
NOORDHUIZEN, J. P. T. M.; FRANKENA, K.; VAN DER HOOFD, C. M.; GRAAF, E. A. M. Application of quantitative methods in veterinary epidemiology, Wageningen: Wageningen Press, 1997. 445 p.

REIS, J. K. P.; DINIZ, R. S.; HADDAD, J. P.; FERRAZ, I. B.; CARVALHO, A. F.; KROON, E. G.; FERREIRA, P. C.; LEITE, R. C. Recombinant envelope protein (rgp90) ELISA for equine infectious anemia virus provides comparable results to the agar gel immunodiffusion. Journal of Virolological Methods, Amsterdam, v. 180, $\mathrm{n}$. 1-2, p. 62-67, 2012.

SANTOS, R. M. L.; REIS, J. K. P.; SANTOS, F. G. A.; OLIVEIRA, I. C. S. Frequência de anemia infecciosa em equinos no Acre, 1986 a 1996. Arquivo Brasileiro de Medicina Veterinária e Zootecnia, Belo Horizonte, v. 53, n. 3, p. 310-315, 2001.

SELLON, D. C. Equine infectious anemia. Veterinary Clinics of North America: Equine Practice, Amsterdam, v. 9, n. 2, p. 321-336, 1993.

SERGEANT, E. S. G. Epitools epidemiological calculators. AusVet Animal Health Services and Australian Biosecurity Cooperative Research Centre for Emerging Infectious Disease. Fremantle: AusVet, 2009. Available at: <http://epitools.ausvet.com.au/content. php?page=home $>$. Accessed at: 20 out. 2010.

THRUSFIELD, M. Veterinary epidemiology. $2^{\text {th }}$ ed. Cambridge: Blackwell Science, 1995. 479 p.

WORLD ORGANISATION FOR ANIMAL HEALTH - OIE. Equine infectious anemia. Manual of diagnostic tests and vaccines for terrestrial animals. Chapter 2.5.6. Paris: OIE, 2012. Available at: <http://www.oie.int/ international-standard-setting/terrestrial-manual/accessonline/>. Accessed at: 10 fev. 2013. 